fleetingly in a broad context of slave trade (p. I 53), and the entire significance of the nineteenth-century Andean highlands will be reduced to their incredible fortune of having been associated with Alexander von Humboldt's "extraordinary" expedition "which took the German naturalist to heights at which no European had ever before stayed for long" (p. 376).

At the final, semantic level, then, the moral to take home is that "history prefers to remember the victors" (p. 916). Having self-consciously purged the histories which try to do otherwise, having explicitly refused to ask the question "Why Europe?" (p. xxi), and having skillfully avoided the thorny question of "modernity" (p. 905), Osterhammel, in spite of his distaste for rash generalizations, in the last pages of this monumental volume finally, if only with a couple of qualifications, pronounces the nineteenth century to have been "a century of emancipation" (pp. 915-918)."For whom?", it may not be very polite to ask.

\title{
Bodhisattva Kar
}

Department of Historical Studies, University of Cape Town Beattie 24I, UCT, Rondebosch 770I, Cape Town, South Africa

E-mail: bodhisattva.kar@uct.ac.za

Beckert, Sven. Empire of Cotton. A Global History. Alfred A. Knopf, New York 2015. xxii, 615 pp. Ill. \$35.00. (Paper: \$18.95.) doi:10.1017/ So020859015000553

Beckert's global history of the rise and fall of the European-dominated empire of cotton is, above all, about the march of capitalism through history. Cotton was not the only the crop to have accompanied this journey, as cereals or sugar were prominent as well, but the author's justification of his choice for this fibre seems, to me, fairly convincing. Cotton accelerated global capitalism: through a unique confluence of mercantile logistics and technological skills, north-west England was catapulted to the economically most advanced stage. There is some irony of history here, because northern Europe was rather peripheral to cotton until its trading companies started to import cloth from India. In this part of the world most people wore monochrome woollens or linen. Southern Europe was a slightly different story since contacts with the expansive Arabic world had acquainted Spain and Italy with cotton centuries before. Thanks to the busy trade route from Venice to Augsburg, cotton crossed the Alps, where the Fuggers became prominent textile industrialists. But this was all rather insignificant compared to the flow of cotton goods from India to Europe in the eighteenth century.

While India and China were still by far the world's most important industrial producers, peripheral Europe succeeded in changing the trade patterns through superior military power. The argument is well-known: thanks to the military-fiscal state, as well as maritime and financial technology, Europe was able to control territories all over the world, and eventually to recast the web of global connections and to position itself at the centre of this 
web. In contrast to the ongoing debate about how to explain the "great divergence", the role of violence and trade is no longer such a controversial point. See, for example, Findlay's and O'Rourke's Power and Plenty, which concludes that "British military successes overseas played an important role" in explaining why the Industrial Revolution took place in Britain. ${ }^{\mathrm{I}}$ Beckert tags the name "war capitalism" to this violent and slave-based phase of capitalism.

Meanwhile, merchants and producers could rely on the British parliament to take the necessary protective measures, and this protectionism started surprisingly early. Beckert records how, from the early seventeenth century onwards, the British state was called upon by London wool merchants to protect their trade against the influx of Indian textiles with their brilliant colours. There was a drive not only to protect British industry but also to improve its competitiveness and to overcome the wage discrepancy that already existed between north-west Europe and south Asia. The combination of mercantile logistics and advances in using machine-powered spinning turned Lancashire into the core of the empire of cotton.

Interestingly, the Chinese had invented a water-powered spinning wheel even before the thirteenth century, and India and Prussia would have been likely candidates for the quantum leap in spinning productivity that would eventually occur in Lancashire. In two ways Britain and here Beckert directly engages with the "great divergence" debate - differed from the rest of the world. First, because the British were directing the cruel triangle of cotton from India, slaves from Africa, and sugar from the Caribbean. Second, because of Britain's enclosures unleashing the necessary supplies of labour. With this assessment, he deviates from Pomeranz and others who, as is well known, stress the shift in the energetic base of society through coal (apart from pointing to the role of colonies as well). As such, Beckert's points are not novel, but his reconstruction of the interplay between merchants, industrialists, and an increasingly powerful modern state in establishing the empire of cotton is masterful.

The march of capitalism has been paved with cruelties and these were perpetrated in the factories as well as in the early nineteenth-century cotton belt of the US, where the abolition of the slave trade was "compensated" for by the protection of slavery in the southern states in the American Constitution and the forceful relocation of slave populations to the Deep South. The message conveyed in the book is that in the decades preceding the American Civil War, the violent perpetuation of slavery was pivotal to the empire of cotton and a necessary stage towards a new phase of capitalism, namely industrial capitalism. What distinguishes industrial capitalism fundamentally from previous war capitalism, Beckert points out, is that it did not concentrate economic power in the hands of a few merchants but dispersed it together with the spread of industrial technology. Yet, until the mid-nineteenth century this happened almost exclusively in the North; promises of industrial breakthroughs in the Global South, such as in Egypt, were not fulfilled. Egypt, according to Beckert, was neither capable of creating the required proletarian industrial workforce, nor was it in a position to protect its infant industry against British imports. At that time the countries of the Global South were simply overpowered by British interests and designs.

With regard to mobilizing a proletariat, we might encounter a weak point in Becker's argument as he does not further elaborate on the absence of the industrial proletariat in Egypt.

I. Ronald Findlay and Kevin H. O'Rourke, Power and Plenty. Trade, War, and the World Economy in the Second Millennium (Princeton, NJ [etc.], 2007), p. 352. 
I think the labour history of the early nineteenth-century Egyptian cotton industry - and the other contemporary, later to fail industries in Brazil or Mexico for that matter - deserves further study. In my view, it is not just the combination of state power to control labour that is crucial here; the composition of the available labour force in relation to gender and skills/ education at the start of industrialization should be taken into account as well.

In any case, the Global South, as is well known, did not industrialize but became the provider of raw material. The interests of industrial capitalism and the state had become so intertwined that, when the American Civil War broke out, the global panic about the possible dismemberment of the empire of cotton culminated in a frantic global incorporation of land and labour into cotton production, in which colonial states and industrial as well as mercantile capitalists closely collaborated. These were not necessarily the capitalists from the respective colonial state, as the development of the Swiss Volker cotton merchant house in British India demonstrated. In the second half of the nineteenth century its dense network of cotton purchasers had deeply penetrated the Indian countryside, sidelining or subsuming Indian cotton purchasers who were not able to accomplish the same degree of vertical integration in their purchase and sales organization. Indian peasant income was now directly tied to the whims of consumer markets in London, Paris, and New York. Cotton mono-cropping, which may have been profitable for peasants at the times of high cotton prices and low food prices, led to devastating famines when the trend was reversed. However, global capitalism on its march did not conquer all corners of the world; in many places, local industries, such as homebased spinning and particularly weaving, survived.

Exactly at the time of complete peripheralization of large swathes of the Global South in the empire of cotton, in another twist of history, the Global South "returned" with surges of industrialization in Bombay, Japan, and Brazil. Acquiring a textile industry became a key issue in programmes of economic nationalism advocated by wealthy members of nationalist elites. Later, the geography of cotton was dramatically reordered again in the twentieth century, with China and India together accounting for one-half of the cotton growing in the world. Moreover, the role of the state had become increasingly subservient to the interests of the large, vertically integrated apparel businesses. The suffering of the cotton-growing peasants and workers in the garment industries are the continuing dark side of the tremendous decline of the cost of clothing in relation to per capita income in the industrial world. This is the Janus-headed march of global capitalism, which, on the one hand, has raised productivity and living standards, but, on the other, has been violent and relentlessly exploitative, leading in numerous instances to relative and even absolute impoverishment.

Modern global history as a history of connections owes much to the narrative tradition of history writing that goes right back to the master, Leopold von Ranke. This book may seem unapologetically historicist as it tells the story "of how it really was", but the careful reader will see more of Hegel in the way in which the march of capitalism is narrated as gruesomely oppressive but also liberating. For those who love to read a great narrative, composed with meticulous care and written in a literary style about a subject that concerns us all, this book will be a source of pleasure. They are either the non-professional reader enjoying its accessibility or the global historian for whom not every relevant academic debate needs to be spelled out. What sticks after reading the book is that it is an audacious step towards grasping the nature of capitalism. The way in which it is done shows that Beckert belongs to the select group of 
historians who are able to converse directly with the world outside the ivory tower in great style and without simplifications.

\author{
Ulbe Bosma \\ International Institute of Social History \\ PO Box 2 169, I000 CD Amsterdam, The Netherlands \\ E-mail: ubo@iisg.nl
}

Guasco, Michael. Slaves and Englishmen. Human Bondage in the Early Modern Atlantic World. [The Early Modern Americas.] University of Pennsylvania Press, Philadelphia 20I4. 315 pp. Ill. £29.50. doi:I0.1017/ So0208590I 500054 I

In this extremely well-researched book, Michael Guasco, Associate Professor of History at Davidson College, has made an important contribution to the study of slavery in the Atlantic world of the late sixteenth and early seventeenth centuries. With a primary focus on the emergence of slavery in the English New World colonies, he has much to add to the evolution of ideas concerning slavery in England and the influence of the Spanish in their colonies on English developments. He also has discussions of the patterns of behavior of the other European settlers of the Americas, the importance of European knowledge of slavery in Africa, and the treatment of Native Americans in various parts of the Americas.

The main contributions of Guasco concern the basic attitudes of the English towards what they called slavery and the importance of the Spanish in framing the English understanding of slavery in the New World. Slavery was a concept well-known to Englishmen at this time, and there are numerous debates and discussions about its meaning and its presence in England and its colonies even before its establishment in the colonial empire. An important background to the English concept of slavery had been the earlier system of slavery that had emerged in the Spanish colonies. The Spanish had settled in the Americas, and the Portuguese in Brazil and India, a century before the English arrivals. In many ways the English in the Americas had a precedent established by the Spanish either to follow or otherwise react to, depending on local conditions. For these reasons there was no need for the English to start completely fresh with legal and other arrangements regarding enslavement.

Guasco thus starts from the premise that the English reactions to slavery were influenced by their past knowledge of what they, and other nations, had experienced as slavery. The English did regard themselves as exceptional in that their citizens were considered free from enslavement and enjoyed more freedom than citizens of other nations. The presumed exceptionalism, as Guasco points out in detail, was greatly exaggerated since variants of coerced labor had existed (and continued to exist), although presumably to a lesser extent than elsewhere.

There were contemporary discussions comparing the differences between slaves and servants, based on the duration of the period of coercion and the punishments permitted. After the introduction of indentured servitude, it was often described as slave-like to distinguish it from actual slavery. Initially slavery was regarded by the English not as a measure to increase the amount of labor, as was later the case with African slaves. Rather, it was then usually justified 